\title{
Sergio Pitol, czyli o związkach między literaturą Europy Środkowej i Ameryki Łacińskiej
}

Agnieszka Hudzik

TEKSTY DRUGIE 2020, NR 4, S. 350-366

DOI: 10.18318/td.2020.4.19 | ORCID: 0000-0001-7454-7752

A rtykuł dotyczy związków literackich między Euro-


twórczości meksykańskiego pisarza Sergio Pitola. Był on autorem ponad dwudziestu pięciu książek, w tym powieści, zbiorów opowiadań i esejów, otrzymał za nie wiele prestiżowych nagród, zmarł przed dwoma laty, w kwietniu 2018 roku. Oprócz własnej działalności pisarskiej zajmował się również przekładem literackim, tłumaczył z mało popularnych w Hispanoameryce języków, np. z węgierskiego i polskiego, m.in. prozę Witolda Gombrowicza, Jerzego Andrzejewskiego i Brunona Schulza. Pracował także jako dyplomata, kilka lat spędził w Warszawie, był też ambasadorem w Czechosłowacji. Pełnił funkcję łącznika kulturowego, w swojej twórczości poruszał temat kanonu literatury światowej, starał się go na nowo zdefiniować, konsekwentnie wprowadzając do niego dzieła literackie z krajów środkowoeuropejskich i latynoamerykańskich.

Tekst składa się z pięciu części. Rozpoczynam od naszkicowania szerszej ramy interpretacyjnej dla pisarstwa
Agnieszka Hudzik

- Dr. phil., adiunkt na Friedrich Schlegel Graduate School of Literary Studies, Freie Universität Berlin. Ostatnio opublikowała monografię: Philosophie der Verführung in der Prosa derModerne (2018). Kontakt:a.hudzik@ fu-berlin.de 
Pitola, którą tworzą spostrzeżenia Milana Kundery na temat literackich związków między Europą Środkową i Ameryką Łacińską. Zdają się one bowiem niejako ucieleśniać w dziele Pitola - literackiego obieżyświata, łączącego w sobie tradycje obydwu tych odległych od siebie, geopolitycznych i geopoetycznych, regionów świata. Po tych rozważaniach w części drugiej przedstawiam życie i twórczość meksykańskiego autora. W części trzeciej omawiam jego związki z Polską i kontakty z polskimi pisarzami, głównie na podstawie jego wspomnień zawartych w dziele El arte de la fuga (1996). Część czwartą poświęcam wizji literatury i roli pisarza według Pitola. Na koniec piszę o recepcji i perspektywach badawczych jego twórczości.

\section{Kundera i komparatystyka literacko-kulturowa}

Kundera w swoich esejach, zamieszczonych w zbiorach pod tytułem Sztuka powieści, Zdradzone testamenty, Zastona czy Spotkanie, często podkreśla związki między literaturami środkowoeuropejskimi i latynoamerykańskimi. Do ich opisu używa sugestywnych metafor. Widzi „srebrzysty most, lekki, drżący, błyszczący", który ma wyginać się niczym tęcza nad XX wiekiem „między moją małą Europą Środkową i ogromną Ameryką Łacińską"1. Pisze o „nieoczekiwanym sąsiedztwie"2 i „zadziwiającym pokrewieństwie"3 obu regionów. Jego zdaniem te dwie części świata odegrały kluczową rolę w historycznym rozwoju powieści jako gatunku literackiego. Najpierw Europejczycy, Franz Kafka, Robert Musil, Hermann Broch i Witold Gombrowicz w latach 20. i 30. ubiegłego stulecia mieli otworzyć dla niej nowe możliwości estetycznie, później przyszła kolej na pisarzy latynoskich, takich jak Juan Rulfo, Alejo Carpentier, Ernesto Sábato czy Carlos Fuentes - najważniejszych kontynuatorów przemian estetyki powieściowej ${ }^{4}$. Kundera zwraca uwagę na ich wzajemne podobieństwa: wszyscy chętnie eksperymentują z formą i przełamują estetykę realizmu, co chciałby tłumaczyć faktem, że oba regiony zostały naznaczone „pamięcią historyczną o baroku”, wyjątkowo uczulającym „na urok wyobraźni fantazjującej, feerycznej, onirycznej"5. Kundera nie rozwija przy tym żadnej

1 M. Kundera Zasłona, przeł. M. Bieńczyk, PIW, Warszawa 2006, s. 80.

2 Tamże, s. 79.

3 M. Kundera Spotkanie, przeł. M. Bieńczyk, PIW, Warszawa 2009, s. 71.

4 Tamże, s. 71-72.

5 Tamże, s. 71. 
teorii wpływu - nie chodzi mu o ukazanie chronologicznych zależności między pisarzami, według których młodsi mieliby naśladować i rozwijać pomysły starszych. Nie postrzega historii powieści w linii prostej, literatura powstaje według niego w sieci skomplikowanych powiązań. W jednym z esejów zauważa, że dopiero w świetle trylogii Terra Nostra Fuentesa (1975) Lunatycy Brocha (1929-1932) „ujawniają cały ogrom swej estetycznej nowości, która w chwili, gdy powieść się ukazała, była ledwie dostrzeżona"6.

Komparatystyczne obserwacje Kundery mają oczywiście swoje konteksty biograficzne. W 1968 roku w Pradze spotkał się on z Julio Cortázarem, Gabrielem Garcíą Márquezem i Carlosem Fuentesem, którzy przyjechali tam w geście solidarności wkrótce po inwazji wojsk rosyjskich?. Po latach tak wspominał ich wizytę: „Przyjechali bez fanfar, jako ludzie pióra. Aby zobaczyć. Aby zrozumieć. Aby podtrzymać na duchu czeskich kolegów. Spędziłem z nimi niezapomniany tydzień. Zaprzyjaźniliśmy się"8. Później, już na emigracji w Paryżu, zacieśnił przyjaźń z Fuentesem. Przyznawał, że czytając jego powieści, po raz pierwszy miał poczucie, że jest „związany z innymi”. Poznał też Octavio Paza - jego imię ${ }^{10}$ zamieścił nawet w eseju-słowniku pośród słów kluczy ważnych dla swojej twórczości.

Pomysł na transatlantyckie powinowactwa z wyboru między literaturami z Europy Środkowej i Ameryki Łacińskiej tłumaczą jednak nie tylko fakty z biografii czesko-francuskiego pisarza. Mowa tu przede wszystkim o integralnej części jego koncepcji Europy Środkowej, wciśniętej między dwa imperia - rosyjskie i niemieckie. Siły zewnętrzne przedzieliły ją żelazną kurtyną, niszcząc w ten sposób historycznie ukształtowaną policentryczną całość. Stopniowo miała ona zniknąć z mapy Zachodu i zostać zapomniana przez zachodnioeuropejskich intelektualistów. Kundera często odwoływał się dlatego do tradycji literackich imperium Habsburgów, będącego swoistym "laboratorium zmierzchu"11, starał się ożywić ten obszar kulturowy i myśleć o nim poza podziałami zimnowojennymi. Otóż dla takiego to właśnie

6 M. Kundera Zasłona, s. 154.

7 O spotkaniu pisarzy w Pradze zob. J. Vervaeke Un puente plateado. Kundera, Fuentes, García Márquez y Cortázar en 1968, „Romaneske” 2018 nr1, s. 79-86.

M. Kundera Zasłona, s. 78.

M. Kundera Zdradzone testamenty, przeł. M. Bieńczyk, PIW, Warszawa 1996, s. 18.

M. Kundera Sztuka powieści, przeł. M. Bieńczyk, W.A.B., Warszawa 2015, S. 162.

M. Kundera Sztuka powieści, s. 147. 
sposobu myślenia znalazł podobieństwa historyczno-polityczne, a także wsparcie intelektualne na subkontynencie latynoamerykańskim - oba regiony postrzegał jako „dwa obrzeża Zachodu usytuowane na przeciwstawnych krańcach; dwie zaniedbane, pogardzane, porzucone ziemie, ziemie pariasy"12. To dla nich XX wiek zgotował tragiczne doświadczenia: wojny, dyktatury, upadki systemów i przewroty polityczne. Czytając esej Kundery o tragedii Europy Środkowej ${ }^{13} \mathrm{z} 1983$ roku i przemówienie noblowskie Gabriela Garcíi Márqueza z 1982 roku, nie sposób nie zauważyć podobieństw w argumentacji i ocenie sytuacji politycznej. Márquez także pisze o ucisku, intelektualnym porzuceniu i braku zrozumienia ze strony Europy Zachodniej - o „samotności Ameryki Łacińskiej"14, którą uczynił głównym tematem swoich Stu lat samotności (1967). Literatura, a przede wszystkim powieść, stała się zarówno dla Kundery, jak i dla Márqueza schronieniem dla doświadczeń jednostki poza narzuconymi podziałami politycznymi i narodowymi - schronieniem dla samotnych, zapomnianych i niezrozumianych.

Kundera pisze w ten sposób nie tylko manifest polityczny, wymowny w czasach zimnej wojny. Wskazuje na sieć uwikłań estetyczno-poetologicznych i otwiera tym samym intrygującą perspektywę dla badań komparatystycznych, opartą na aksjologii, wedle której „konteksty narodowe i regionalne są nieprzydatne, kiedy pragnie się uchwycić znaczenie i wartość dzieła"15.

Wydaje się, że zwolennikiem tego samego poglądu jest bohater poniższych rozważań - Sergio Pitol, jeden zgłównych aktorów na scenie wymiany literacko-kulturowej między krajami środkowoeuropejskimi i latynoamerykańskimi. Jego twórczość niemal idealnie nadaje się do interpretacji w perspektywie zarysowanej przez Kunderę, którą współcześni komparatyści, jak np. Ottmar Ette, określają mianem badań transarealnych (TransArea Studies).

\section{Transatlantycki łącznik}

Pitol urodził się w 1933 roku w mieście Puebla, oddalonym od stolicy Meksyku o około $130 \mathrm{~km}$ na południowy wschód. W wieku czterech lat stracił

12 M. Kundera Zasłona, s. 79/80.

13 M. Kundera Zachód porwany albo tragedia Europy Środkowej, "Zeszyty Literackie" 1984 nr 5 , S. $18-24$.

14 G. G. Márquez The Solitude of Latin America (Nobel Lecture, 8.12.1982), https://www.nobelprize. org/prizes/literature/1982/marquez/lecture/ (15.08.2020).

15 M. Kundera Sztuka powieści, s. 147. 
rodziców, zmarła też jego siostra. Razem ze starszym bratem wychowywał się u dziadków ze strony matki w małym miasteczku w prowincji Veracruz. Jako dziecko długo chorował na malarię i był przykuty do łóżka, po latach wspominał, że to dzięki książkom, które czytała mu babcia, wyzdrowiał. Od tamtej pory literatura stała się dla niego najważniejszą rzeczą na świecie. Mimo tej fascynacji, idąc na studia, wybrał prawo na Narodowym Uniwersytecie Autonomicznym Meksyku. Uczęszczał jednak na zajęcia z filozofii, literatury i sztuki, m.in. u takich sław jak dramatopisarz Rodolfo Usigli czy malarz i architekt Juan O'Gorman. Po ukończeniu studiów, wstąpił w 1960 roku do meksykańskiej służby dyplomatycznej i przez prawie trzy kolejne dekady podróżował po całym świecie, łącząc pracę dyplomaty z twórczością literacką. Warto dodać, że w tamtych czasach taka droga kariery była typowa dla meksykańskich pisarzy, wystarczy wspomnieć Paza czy Fuentesa.

Sergio Pitol pracował jako attaché kulturalny we Francji, na Węgrzech, w Polsce oraz w Związku Radzieckim, był również ambasadorem w Czechosłowacji. Ponadto mieszkał w Rzymie, Londynie i Pekinie, gdzie pracował jako tłumacz na krótko przed rewolucją kulturalną. Po krwawych wydarzeniach w Meksyku w 1968 roku, zwanych Masakrą na placu Trzech Kultur - brutalnej pacyfikacji manifestacji studenckiej przez siły rządowe w dzielnicy Tlatelolco - w ramach protestu zrezygnował na jakiś czas z dyplomacji i zatrudniał się w wydawnictwach, m.in. w Tusquets Editores w Barcelonie, w którym koordynował przekłady literackie. Następnie znowu dołączył do korpusu dyplomatycznego, do Meksyku powrócił ostatecznie na początku lat 9o., osiedlił się w Xalapie, stolicy Veracruz, gdzie nauczał na tamtejszym uniwersytecie.

Jego twórczość obejmuje powieści, zbiory opowiadań i esejów. Niestety tylko nieliczne z nich ukazały się w języku polskim. W formie książkowej to raptem tylko pierwsza powieść z 1972 roku Dźwięhfletu ${ }^{16}$ - utwór wielowątkowy, o wyszukanej strukturze narracyjnej, z ciekawą konstelacją bohaterów związanych ze światem sztuki, pełen metarefleksji o literaturze. Do tego dochodzą jeszcze dwa zbiory opowiadań, wydanych w latach 6o. i 70.: Każdyze swoim piektem ${ }^{17}$ oraz Przedślubne spotkanie ${ }^{18}$. Ponadto czytelnicy w Polsce mogli się natknąć na krótsze teksty Pitola, sięgając po polskie wydania klasycznych

16 S. Pitol Dźwięk fletu, przeł. K. Wojciechowska, Czytelnik, Warszawa 1975.

17 S. Pitol Każdy ze swoim piekłem, przeł. Z. Szleyen, K. Wojciechowska, Iskry, Warszawa 1967.

18 S. Pitol Przedślubne spotkanie, przeł. Z. Szleyen, A. Sobol-Jurczykowski, Wydawnictwo Literackie, Kraków 1974. 
pozycji literatury meksykańskiej: jest on m.in. autorem posłowia do mikropowieści Pedro Páramo, starszego od siebie o pokolenie prekursora realizmu magicznego - Juana Rulfo.

Utworów Pitola nie sposób jednak jednoznacznie zaklasyfikować, zrywają one bowiem z dominującymi nurtami w literaturze Ameryki Łacińskiej i grają europejskimi stereotypami na jej temat. Być może to jeden z powodów, jak twierdzą badacze, dla których jego książki są rzadziej tłumaczone i mniej znane poza hiszpańskojęzycznym kręgiem kulturowym. To pewien paradoks, ponieważ mają wymiar uniwersalny, ponadkulturowy, pobrzmiewa w nich echo gigantów Weltliteratur. Uznanie przyniosła mu powieść kryminalna El desfile del amor [Parada miłości, 1984], nawiązująca w tytule do filmu Ernsta Lubitscha z 1929 roku. Autor mówił o niej w komentarzach, że to hołd złożony jego opiekuńczym bogom, do których zaliczał Gogola, Bustos Domecqa i Gombrowicza.

W kolejnej powieści Domar a la divina garza [Okiełznać boską czaplę, 1989] zostaje wspomniany Bachtin i Rabelais, w tekście aż kipi od intertekstualnych aluzji do tradycji género chico, hiszpańskiej formy komediowej, do powieści łotrzykowskiej hiszpańskiego Siglo de Oro, do antropologicznych teorii Bronisława Malinowskiego, wreszcie, do poczucia humoru znanego z utworów Noël Cowarda, Francisco de Quevedo czy Alfreda Jarry'ego. Słowem, książka-kocioł, a w nim mikstura z najlepszych składników. Na marginesie warto dodać, że dwie wspomniane powyżej powieści Pitola razem z następną zatytułowaną La vida conyugal [Życie małżeńskie, 1991] ukazały się jako trylogia i zostały zebrane w tomie Tríptico del carnaval [Tryptyk karnawałowy, 1999].

Polską publiczność mogłaby jednak szczególnie zainteresować inna trylogia jego autorstwa, a mianowicie Trilogía de la memoria [Trylogia pamięci, 2007], na którą składają się El arte de la fuga [Sztuka ucieczki/fugi, 1996], El viaje [Podróż, 2000] oraz El mago de Viena [Magik z Wiednia, 2005]. Są to zbiory tekstów o podróżach i literaturze, opartych na fabularyzowanych wątkach autobiograficznych - niektóre z nich, zawarte zwłaszcza w pierwszym tomie, dotyczą pobytu pisarza w PRL-owskiej Warszawie. Wspomnienia nie są ułożone chronologicznie, pojawiają się w tekstach, w których krzyżują się różne gatunki, od opowiadania po esej. Granice między rzeczywistym a zmyślonym zacierają się. Trywialne zapiski i plotki z artystycznego półświatka i kawiarni literackich łączą się z niezliczonymi dygresjami i przemyśleniami na temat sztuki. W wywiadzie dla czasopisma „Literal” Pitol nazwał El arte de la fuga jedną ze swych „najbardziej intensywnych i rozrywkowych 
książek"19 , która w trakcie pisania wywoływała w nim skrajne emocje, od bólu po śmiech i radość. Fascynują w niej zwłaszcza bogate skojarzenia autora związane z literaturą. Autor to bowiem literacki obieżyświat, oczytaniem dorównujący George'owi Steinerowi czy Erichowi Auerbachowi. Konsekwentnie rewiduje on kanon i rozszerza go o twórców, niekoniecznie reprezentujących światowe imperia, powołując się chociażby na dzieła Witkacego czy Augusto Monterroso z Gwatemali.

Swobodne poruszanie się po literaturach różnych części świata jest dowodem nie tylko na podróżniczy tryb życia Pitola, lecz także na jego geniusz literacki i językowy. Znał on co najmniej siedem języków. Przetłumaczył wiele książek z języka angielskiego - np. utwory Henry'ego Jamesa, Jane Austen czy Josepha Conrada; z włoskiego (Giorgio Bassani, Giuseppe Berto i Luigi Malerba); z rosyjskiego (Czechow czy Nabokov); z węgierskiego (Tibor Déry) oraz z polskiego - a tu lista jego przekładów jest bardzo długa. Do tłumaczonych pisarzy należeli m.in. Jerzy Andrzejewski, Tadeusz Borowski, Kazimierz Brandys, Maria Dąbrowska, Stanisław Dygat, Witold Gombrowicz, Marek Hłasko, Jarosław Iwaszkiewicz, Ryszard Kapuściński, Andrzej Kuśniewicz, Bolesław Leśmian, Sławomir Mrożek, Zofia Nałkowska, Tadeusz Różewicz, Adolf Rudnicki i Bruno Schulz. Oprócz przekładów Pitol pisał także często wprowadzenia i posłowia do polskich książek publikowanych w Meksyku - uchodził za znawcę, propagatora i entuzjastę literatury polskiej, działał niczym „dyfuzor" literacki, rozprzestrzeniając wiedzę o Polsce w hiszpańskojęzycznym świecie. Za wybitne zasługi w rozwijaniu dialogu transatlantyckiego i polsko-meksykańskiej współpracy kulturalnej został odznaczony w 1998 roku Krzyżem Oficerskim Orderu Zasługi Rzeczypospolitej Polskiej. To tylko jedno z symbolicznych wyróżnień wśród wielu prestiżowych nagród, którymi go uhonorowano za całokształt twórczości literackiej: w 2005 roku otrzymał Nagrodę Cervantesa, a w 2015 roku Międzynarodową Nagrodę Alfonso Reyesa.

\section{Związki z Polską}

Pewnej mroźnej nocy młody Meksykanin wraca do Warszawy pociągiem z Łodzi, gdzie odwiedził swojego przyjaciela. Podróż ta okazuje się dla niego wyjątkowa. Naprzeciwko siada starsza kobieta, która do złudzenia

19 P.M. Domene The Return of the Magician: A Conversation with Sergio Pitol, "Literal” https://literalmagazine.com/the-return-of-the-magician-a-conversation-with-sergio-pitol/ (15.08.2020). 
przypomina mu jego ciotkę - zmarłą siostrę babki. Znał ją jedynie z dawnych fotografii i legend rodzinnych: spotkał ją nieszczęśliwy los. Przed wieloma laty miała utonąć na pełnym morzu, powracając z podróży poślubnej. Czy to możliwe, że to ona? Jak tu się teraz znalazła? Czy to jedynie zjawa, efekt halucynacji i gorączki?

Tak rozpoczyna się opowiadanie Pitola Hacia Varsovia [W stronę Warszawy] z 1963 roku, opublikowane w tomie Los climas (1966) - pierwsze, które napisał w trakcie swojego pobytu w Polsce. Tekst zawiera wątki autobiograficzne. Autor w komentarzach relacjonuje, że bardzo długo pracował nad tą iście gotycką historią: zależało mu na osiągnięciu efektu artystycznego, który w tym czasie nazwano realizmem magicznym (klasyczne dzieło z tego gatunku, Sto lat samotności Márqueza, przypomnę, ukazuje się po raz pierwszy w 1967 roku). Polega on na tym, że rzeczywiste i nierzeczywiste splata się w niej w jedno bez widocznych „szwów”. To przenikanie się sytuacji prawdopodobnych i niemal nieprawdopodobnych, jak z przysłowiowej powieści, zdawało się też charakteryzować jego życiorys.

Na intrygujący rozdział o Polsce w biografii Sergio Pitola składają się dwa jego dłuższe pobyty w Warszawie, gdzie pracował od 1963 do 1966 roku jako korespondent oraz w latach 1972-1975 jako attaché kulturalny Ambasady Meksyku. W swoich wspomnieniach, zawartych m.in. w przywołanym już tomie El arte de la fuga, stolica Polski o dziwo nie ma w sobie nic z szarej komunistycznej codzienności. To tętniąca życiem artystycznym światowa metropolia. Tak pozytywne impresje są z pewnością efektem uprzywilejowanej pozycji Pitola, który chociaż za żelazną kurtynę przybył z tzw. trzeciego świata, to jednak w roli "egzotycznego" gościa z dewizami. Przez długi czas mieszkał w centrum, w Hotelu Bristol. W mieszczącej się w nim restauracji widział ówczesne sławy wielkiego formatu: Marlenę Dietrich, Jacques'a Brela, Petera Brooka, Artura Rubinsteina, Claudio Arrau, Giorgio Strehlera, Ellę Fitzgerald czy Luchino Viscontiego. Ale to nie zagraniczne osobistości robią wrażenie na Pitolu, bynajmniej nie zachwyca się blichtrem gwiazd. I nie jest oderwany od rzeczywistości. Świetnie orientuje się w tym, co dzieje się wokół, jest świadom sytuacji politycznej w kraju, dociekliwie studiuje literaturę i kulturę polską, śledzi debaty intelektualistów, uczy się języka.

Pierwszy pobyt Pitola w Warszawie to czas odwilży po 1957 roku: w księgarniach jest już więcej książek - ukazują się dzieła Andrzejewskiego, Brandysa, Gombrowicza, Kołakowskiego, Kotta, Mrożka, wydano wznowienie opowiadań Schulza - a w teatrach bardziej urozmaicony repertuar. Ale to przede wszystkim wyjątkowy okres w życiu Pitola - czas rozwoju jego 
pisarskiej osobowości. Jako młody, trzydziestoletni człowiek utwierdza się w swoim powołaniu literackim, przeżywa rozterki i kryzysy, nierozerwalnie związane z życiem artysty. Swój stan czasami porównuje z losem Tonio Krögera. Podobnie jak bohater noweli Thomasa Manna, on też musi toczyć wewnętrzną walkę między uleganiem pokusom doczesnym a twórczą samotnością - między pragnieniem świata a koniecznością odwrócenia się od niego.

Chcąc zilustrować tę aporię, Pitol w El arte de la fuga wraca pamięcią do pewnego majowego popołudnia w Warszawie: siedząc na parapecie w pokoju hotelowym na najwyższym piętrze Bristolu, zachwyca się widokiem. Na Krakowskim Przedmieściu tłum ludzi, to musi być piątek, bo jest większy ruch niż zazwyczaj. Jest piękny słoneczny dzień, w parku nieopodal kwitnie bez, wszędzie widać zwiastuny wiosny. Na biurku leży mnóstwo papierów. Pitol szykuje właśnie antologię polskich opowiadań współczesnych, czyta, wybiera, tłumaczy i koryguje teksty, równocześnie stara się szlifować własną prozę. W przerwie popija kawę i obserwuje ludzi za oknem, snuje przypuszczenia, wymyśla im historie, tworzy z nich postaci literackie i wplata je w swoje opowiadanie, by po chwili wrócić z powrotem do tłumaczenia Tataraku Iwaszkiewicza, który następnie w dłuższej dygresji zestawia z filmem Zmysty Viscontiego. Mnóstwo skojarzeń, literatura i życie przenikają się, pisarz próbuje się skoncentrować, a przez uchylone okno wpada do pokoju ciepłe, wiosenne powietrze. Wspomina, że w Warszawie odnalazł idealną atmosferę do pisania. Tylko o czym tu pisać, skoro materiał na dobre opowiadanie znajduje się na zewnątrz: na ulicy, w parku czy w kawiarni? Tam pulsuje prawdziwe życie, a nie na poddaszu, gdzie samotny artysta zmusza się do pracy, jakby sam sobie wymierzał karę. Ale czy odwrotna sytuacja też nie byłaby złym rozwiązaniem? Gdyby siedział w knajpie, mógłby go przecież dopaść smutek i wątpliwości, czy nie byłby szczęśliwszy, pracując w domu i np. czytając pisma Jana Kotta o Szekspirze. Jedyną ucieczkę przed takimi oto rozważaniami widzi w pisaniu.

Pitol w Warszawie nie stroni jednak od ludzi - wręcz przeciwnie. Do grona jego bliskich przyjaciół należeli Zofia Szleyen, tłumaczka literatury hiszpańskiej, i Marek Keller, kolekcjoner i marszand sztuki współczesnej, który na początku lat 70. opuścił Polskę. To dzięki pośrednictwu Pitola Keller poznał Juana Soriano, słynnego meksykańskiego malarza i rzeźbiarza, i zaczął prowadzić jego interesy. Zajmował się sprzedażą jego dzieł, a po śmierci artysty założył fundację jego imienia na rzecz promocji sztuki. Przed kilkoma laty polska prasa pisała o Kellerze jako wspaniałomyślnym darczyńcy, 
który podarował Muzeum Chopina w Warszawie warte miliony dolarów listy kompozytora, kupione na jednej z aukcji. To Keller wprowadzał Pitola w życie towarzyskie stolicy, wyciągał go do teatru, na przedstawienia i przyjęcia. To dzięki niemu poznał on - jak sam przyznaje - nocne otchłanie miasta, głośne pijatyki czy odyseje przez modne lokale, z których zwykło się wracać na drugi dzień w okolicach śniadania.

Warszawa dla Sergio Pitola to również miejsce spotkań z ważnymi literatami. Jednym z nich był Jerzy Andrzejewski. Na początku swego pobytu w Polsce Pitol otrzymał egzemplarz Ciemności kryją ziemię we włoskim tłumaczeniu i nie mógł uwierzyć, że taka książka mogła ukazać się w kraju bloku wschodniego. Był głęboko poruszony sposobem, w jaki ta powieść o inkwizycji w XV-wiecznej Hiszpanii obnaża uniwersalne mechanizmy władzy i opresji. Widział też jej adaptację sceniczną, napisaną przez Andrzejewskiego - wspomina, że do teatru ciągnęły na nią tłumy, a samo przedstawienie miało charakter ćwiczenia duchowego albo egzorcyzmu, ale unikało kaznodziejskiego tonu.

Andrzejewski opisany przez Pitola w El arte de la fuga to postać intrygująca i ambiwalentna - człowiek o wielkiej inteligencji i wrażliwości, ale także nieco zamknięty w sobie moralista o ostrych sądach. Po raz pierwszy Pitol zobaczył go na większym spotkaniu, na którym ktoś ich sobie przedstawił. Andrzejewski perorował o Zbrodni i karze, był w złym humorze, wzruszał często ramionami i wyjaśniał, że Polacy nigdy nie zrozumieją Dostojewskiego, gdyż w jego twórczości interesuje ich tylko aspekt religijny, a ich myślenie ogranicza katechizm. Z literatury iberoamerykańskiej czytał dzieła Alejo Carpentiera Podróż do źródet czasu i Eksplozja w katedrze. Dzisiaj wiemy skądinąd, z jego dzienników, że nie był jej miłośnikiem. „Ponieważ wbrew modzie - pisał - wyjątek czyniąc dla utworów Marqueza, rzeczywiście wielkiego pisarza, niedobrze na ogół odbieram prozę tych wszystkich Cortazarów, Carpentierów i Borgesów"20. Mówił, że w sztuce powieści ceni przede wszystkim prawdziwe wyzwania i wielką formę, polscy autorzy współcześni stali się dla niego zbyt ociężali. Ktoś w grupie zapytał, co sądzi o Iwaszkiewiczu. Andrzejewski uśmiechnął się sarkastycznie i w odpowiedzi użył potocznego słowa, którego Pitol nie zrozumiał, a które wywołało powszechne rozbawienie.

Spotkali się jeszcze kilkakrotnie. Pitol pracował wówczas nad tłumaczeniem Bram raju. Długo starał się, żeby znaleźć wydawcę, rozesłał wiele ofert, aż w końcu udało mu się zdobyć umowę. Andrzejewski nie mógł uwierzyć,

20 J. Andrzejewski Z dnia na dzień. Dziennik literacki, t. 2, Czytelnik, Warszawa 1988, s. 206. 
że jego książka ukaże się w kraju, o którym tak mało wie - że jego powieść o mrocznym epizodzie ze średniowiecza, szaleńczej krucjacie dzieci, które szły do Jerozolimy, żeby wyzwolić Grób Pański z rąk innowierców, może kogokolwiek zaciekawić w Meksyku. To było dla niego zbyt abstrakcyjne, dlatego Pitol odniósł wrażenie, że jest mu raczej wszystko jedno, jak wypadnie przekład. Na pytania dotyczące książki odpowiadał szybko i zdawkowo, ale był ciekawy doświadczenia zawodowego swojego przyszłego tłumacza. Ze swoich dotychczasowych przekładów Pitol wymienił Jądro ciemności. Wtedy Andrzejewski wyraźnie się ożywił i odrzekł, że pisarze, którzy go teraz najbardziej interesują, to właśnie Joseph Conrad i Tomasz Mann. Opowiadał, że w młodości przed wojną fascynował się twórczością kilku katolickich powieściopisarzy z Francji, takich jak François Mauriac czy Georges Bernanos, ale po brutalnych doświadczeniach okupacji to zainteresowanie zniknęło. W ich tekstach widział od tamtej pory jedynie dobry warsztat - żadnej głębszej treści. W trudnych latach oparcie znalazł w prozie Conrada i Manna, którą również Pitol bardzo wysoko cenił. Dopiero kiedy Andrzejewski wyczuł, że jego rozmówca ma podobny gust, zmienił swoje nastawienie. Ich rozmowy stały się dłuższe i schodziły na inne tematy. Andrzejewski ganił Polskę, ale i ją usprawiedliwiał, tłumacząc cierpliwie jej tragiczną historię, co Pitolowi przypominało nieco komiczną formę nacjonalizmu. Pitol drążył wątek literatury polskiej, pytał o polskich autorów, na co Andrzejewski machał jedynie lekceważąco ręką. Przyparty do muru, stwierdził, że ważny był dla niego Bruno Schulz.

Oprócz Bram raju Pitol przełożył jeszcze dwie książki Andrzejewskiego: powieść Ciemności kryja ziemię i opowiadanie Niby gaj. Po ukończeniu prac nad tłumaczeniami wspominał moment, gdy ktoś podarował mu Zniewolony umysł. To była dla niego porażająca lektura, czuł, jakby ktoś uderzył go w twarz - trudno mu było uwierzyć w zarysowany przez Miłosza portret pisarza, jego stosunek do władzy i ideologii. Jednak nie stracił sympatii dla Andrzejewskiego - przekład jego dzieł przyniósł niespodziewane skutki. W 1965 roku, kiedy już od dwóch lat mieszkał w Warszawie, otrzymał pewnego dnia list z Vence od Witolda Gombrowicza. Pierwsza myśl: „¡Qué exceso, qué anomalía!"21. To musi być żart! Skąd Gombrowicz o nim wie? Jak go odnalazł? Okazało się, że pisarz miał w ręku Bramy raju po hiszpańsku i przekład tak bardzo mu się spodobał, że zwraca się z prośbą, żeby to Pitol przetłumaczył fragmenty Dziennika odnoszące się do Argentyny, które wydawnictwo Editorial Sudamericana w Buenos Aires chce wydać jako Diario argentino. To było

21 S. Pitol El arte de la fuga, Ediciones Era, México 1996, s. 14. 
przełomowe zlecenie w karierze translatorskiej Pitola, dzięki niemu przez kolejne lata mógł pracować jako wolny tłumacz. Z tekstów Gombrowicza przełożył jeszcze m.in. Kosmos, przebywając w 1969 roku w Barcelonie, Bakakaj oraz, we współpracy z Kazimierzem Piekarkiem, Trans-Atlantyk.

W Beinecke Rare Book and Manuscript Library [Bibliotece Rzadkich Książek i Manuskryptów Beinecke] na Uniwersytecie Yale w New Haven znajdują się materiały archiwalne Witolda Gombrowicza, dokumenty, typoskrypty jego dzieł oraz obszerna korespondencja, w tym listy od Pitola, które miałam okazję przestudiować w trakcie pobytu badawczego w archiwum w 2018 roku. Wiadomości dotyczą spraw technicznych, zwłaszcza pracy nad tłumaczeniem Dziennika. Pitol konsultuje długość rozdziałów, co dokładnie ma wejść w skład argentyńskiego wydania, na niektórych wersjach roboczych spisu treści widnieją odręczne dopiski i korekty Gombrowicza. Ton listów Pitola jest bardzo rzeczowy i profesjonalny, większość z nich jest pisana na maszynie na papierze firmowym z logo Universidad Veracruzana w Xalapie i nagłówkiem Dział Redakcyjny. Prawie wcale nie ma w nich intelektualnej wymiany zdań, prywatnych uwag czy osobistych wynurzeń. W jednym z listów z maja 1966 roku Pitol powiadamia jedynie w krótkim akapicie, że właśnie ukończył tłumaczenie opowiadań Schulza, nad którym długo się męczył. Natomiast w sierpniu 1966 roku pisze, że już na stałe opuścił Warszawę. Zwierza się, że spośród wielu miast, w których przyszło mu mieszkać, to właśnie stolica Polski odcisnęła na nim głęboki ślad. Nie rozwija jednak tego komentarza, nie wyjaśnia, co tak bardzo go urzekło w tym kraju, i szybko informuje o nowym adresie w Meksyku, pod którym będzie teraz dostępny. Dyplomatyczny dystans w korespondencji Pitola kontrastuje z subtelną poufałością i niemal zuchwałością w listach, które pisał do Gombrowicza poprzedni jego tłumacz - kubański pisarz i poeta Virgilio Piñera. Po polsku niedawno ukazał się zbiór jego tekstów Zimne opowiadania ${ }^{22}$. Piñera należał do grupy młodych artystów, którzy w kawiarni Rex w Buenos Aires kolektywnie pracowali nad przekładem Ferdydurke. W jednym z listów tytułuje Gombrowicza "mon vieux copain”, w innych ironizuje na temat jego zarzutów w sprawie błędów w edycji książki. Wyjaśnia, że nawet jeśli jest w niej kilka niedociągnięć, to nie umniejszą one sukcesu powieści, która z pewnością znajdzie wielu czytelników na kontynencie Ameryki Południowej; a jeśli nie - to tylko potwierdzi to fakt, że „my Latynosi" nie mamy respektu dla kultury. Uwaga z przymrużeniem oka, która nie pasowałaby do wyważonego stylu Pitola. 


\section{Wizja literatury}

Sergio Pitol zmarł w wieku 85 lat, od dłuższego czasu nie brał udziału w życiu publicznym, zmagał się z ciężką chorobą - afazją. Kolorowa prasa w Meksyku rozpisywała się o dramacie pisarza-poligloty, który na starość stracił mowę, donosiła w atmosferze skandalu o konflikcie między jego rodziną a przyjaciółmi o opiekę nad nim - ostatecznie żył pod kuratelą państwa.

Był mentorem dla młodszych pokoleń pisarzy. Zastanawiając się, jaki ideowy testament pozostawił po sobie, warto raz jeszcze sięgnąć po jego książkę El arte de la fuga. Krótki szkic poświęca w niej Droctulftowi - jednej ze swoich ulubionych postaci z opowiadania Jorge Luisa Borgesa Historia wojownika i porwanej, z tomu opowiadań Alef. Borges oczywiście odwołuje się w nim do innych tekstów i zaznacza, że opisaną historię znalazł u Benedetta Crocego, ale jej źródeł można doszukiwać się już w kronikach średniowiecznego mnicha benedyktyńskiego Pawła Diakona. Dzieje losów Droctulfta są przejmujące: był on Longobardem, który wraz z wojownikami ze swojego plemienia wędrował w stronę Półwyspu Apenińskiego, chcąc podbić, splądrować i zniszczyć miasta napotkane po drodze. Kiedy jednak ujrzał Rawennę, przeszedł na drugą stronę i zginął w obronie miasta, które miał zamiar zburzyć. Tematem intrygującym Borgesa jest cienka granica między cywilizacją i barbarzyństwem - jego opowiadanie to dla Pitola pretekst do dalszej refleksji na wielu płaszczyznach. W historii Droctulfta widzi najpiękniejszy pean, jaki można wznieść na cześć kultury, rozumianej przez niego szeroko - zróżnicowanej wewnętrznie i otwartej na wpływy niczym Imperium Rzymskie, które charakteryzowała wyjątkowa „przepuszczalność”. Starożytny Rzym czerpał inspiracje z różnych kultur, zaabsorbował wiele z mitologii greckiej i egipskiej oraz z wyobraźni judeochrześcijańskiej.

Pitol dostrzega także zastanawiające podobieństwo między losem Droctulfta a swoim własnym. Longobardzki wojownik - jak powie Borges - nie był zdrajcą, ponieważ jego czyn miał swoje źródło w natchnieniu, w akcie nawrócenia. Zginął w obronie wartości, których nie był w stanie do końca zrozumieć. Taką niepojętą wartością nadrzędną, której bezwzględnie należy bronić, jest dla Pitola literatura. Nie można jej przypisać ani do konkretnego terytorium, ani nawet do języka, nie da się wyznaczyć jej granic, jest jak żywy organizm i przypomina w tym miasto - żywy, ciągle rozprzestrzeniający się i przechodzący metamorfozy przestrzenny palimpsest, na który składają się niezliczone warstwy historii, echa różnych tekstów i wpływów. Literatura w rozumieniu Pitola to sztuka oporu i subwersji - obalania panujących norm i reguł, zastanego porządku rzeczy, wszelkich związanych z nim form opresji 
i niesprawiedliwości. To ostoja humanizmu, utopijna wspólnota otwarta - ojczyzna wszystkich, którzy nie godzą się na zniewolenie, wykluczenie, nieuzasadnioną agresję i destrukcję.

Droctulft to również poniekąd prefiguracja Pitolowskiego narratora i alegoria aktu pisania. W El arte de la fuga autor notuje, że nawet jeśli na pewnym etapie rozwoju jego osobowości twórczej ważną rolę odgrywali pisarze polscy, rosyjscy czy środkowoeuropejscy, a na innym chociażby angielscy, włoscy i latynoamerykańscy, to nigdy nie przyszłoby mu na myśl, że zatraci i zdradzi przez to swój literacki głos: że zada kłam sam sobie, że będzie czuł się obco wobec własnych tekstów, że stworzy narratora, który stanie się dla niego wrogiem, będzie „nieswój” w jego własnym języku. Przeczytane lektury zawsze wzbogacają proces twórczy: to oczywiste, że pisarz musi posługiwać się znakami, które zakodowała w nim kultura, że jego teksty odnoszą się do innych tekstów, ot, znana zasada intertekstualności. Pitol nie ukrywa, że odwołuje się do tradycji literatury światowej i czerpie z niej pełnymi garściami. Jest świadom, że zostawiła ona trwały ślad w jego twórczości, przefiltrowała i naznaczyła jego postrzeganie świata i samego siebie. Niemniej jednak sądzi - i tu ujawnia się jego metafizyczna koncepcja pisarstwa - że nie pozbawiła go własnego głosu, nie ograbiła z oryginalności, nie zachwiała „prawdziwymi" źródłami jego fantazji, nie przeniknęła do głębokich i tajemniczych fałd istnienia, w których spoczywają pierwsze doświadczenia świata i popioły pierwszej miłości. W pisaniu Pitol widzi nieustanną walkę o własny język, nawet jeśli jest on nieporadny, kruchy i zawodny; obronę własnej wyobraźni i wartości, w które się wierzy; walkę o indywidualny styl i sposób artykulacji doświadczenia - wartą podjęcia, nawet jeśli może zakończyć się porażką.

\section{Uwagi na zakończenie - krótko o recepcji}

W historii literatury latynoamerykańskiej Pitol uchodzi za pisarza już kanonicznego, zaliczany jest do generacji Medio Siglo - jest to termin ukuty przez filozofa i historyka Wigberto Jiménez Moreno na określenie literatów, artystów i intelektualistów urodzonych w Meksyku w latach 20. i na początku lat 30. ubiegłego stulecia, odnoszący się również do tytułu poczytnego czasopisma kulturalnego, ukazującego się w drugiej połowie lat 50. Jeśli chodzi o historyczno-literackie przyporządkowania Pitola, to można również spotkać się z pojęciem pokolenia La Casa del Lago, w dosłownym tłumaczeniu: dom nad jeziorem. Było to pierwsze centrum kultury Narodowego Uniwersytetu Autonomicznego Meksyku, założone poza kampusem w 1959 roku przez 
pisarza Juana José Arreolę, które zrzeszało twórców awangardowych i stało się symbolicznym miejscem na kulturalnej mapie miasta.

Mimo niekwestionowanych zasług na polu mediacji transkulturowej nadal zdaje się on jednak pisarzem mało znanym szerszej publiczności w Polsce. Prawda, że relacjom Gombrowicz i Pitol - Gombrowicz w tłumaczeniach Pitola lub intertekstualne nawiązania do Gombrowicza w prozie Pitola - poświęcono wiele artykułów ${ }^{23}$. Brakuje jednak przede wszystkim tłumaczeń jego utworów, a te już wydane są trudno dostępne i czekają na wznowienie. Być może potencjalnych wydawców zachęci obszerna recepcja pisarza, o której na zakończenie warto napisać chociaż kilka słów.

Najwięcej opracowań znajdziemy oczywiście w języku hiszpańskim. Wiele $\mathrm{z}$ nich podejmuje tematy autobiografii, fikcji i pamięci ${ }^{24}$. Badaczy interesuje aspekt intertekstualności i intermedialności, zwłaszcza odniesienia do muzyki, widoczne chociażby w dwuznacznym tytule El arte de la fuga, nawiązującym do ostatniego dzieła Bacha. Fascynują ich także strategie pisarskie Pitola takie jak karnawalizacja i parodia ${ }^{25}$. Szczególną uwagę zwracają na

23 Pisały o tym m.in. Ewa Kobyłecka-Piwońska, członkini zespołu przygotowującego krytyczną edycję dzieł zebranych Gombrowicza (Dziennik i Wędrówki po Argentynie), autorka artykułu "Dziennik argentyński”, czyli jakiego Gombrowicza czyta się w Buenos Aires, "Teksty Drugie" 2016 nr 1, s. 281-302; Bożena Zaboklicka, która wraz z Francesco Miravitllesem przełożyła całość Dziennika Gombrowicza, wydanego w 1988 roku w Madrycie, Gombrowicz po hiszpańsku w przekładach Sergio Pitola, w: K. Ćwikliński, A. Spólna, D. Świtkowska Gombrowicz z przodu i z tyłu, Uniwersytet Technologiczno-Humanistyczny, Radom 2015, s. 45-54; oraz Monika Dąbrowska, która w 2015 roku obroniła na Uniwersytecie Warszawskim doktorat po hiszpańsku o Polsce w dziełach Pitola, Gombrowicz en español a cargo de Sergio Pitol: ¿traducciones irrelevantes o relevante falta de interés?, w: I. Kasperska, I. Villegas, A. Donés Mendia Ideologías en traducción. Literatura, didáctica, cultura, Peter Lang, Frankfurt am Main 2016, s. 69-80.

Zob. m.in. monografię Víctora Hugo Martíneza Gonzáleza o wymyślonych wspomnieniach Sergio Pitol. Una memoria soñada, Universidad Autónoma de Nuevo León, Monterrey 2014; esej Riccardo Pace Sergio Pitol: la novela de una vida un ensayo sobre "El arte de la fuga", Anthropos, Barcelona 2018. O El arte de la fuga traktuje też artykuł Oswaldo Zavali, który interpretuje je jako rozliczenie pisarza z tzw. dziedzictwem kultury zachodniej i pożegnanie z okcydentalizmem: La síntesis y su trascendencia: Sergio Pitol, la escritura autobiográfica y el fin del occidentalismo, "RILCE" 2012 Vol. 28, No. 1, s. 257-272.

Tu m.in. rozprawa Karima Benmilouda Sergio Pitol ou le carnaval des vanités, Presses universitaires de France, Paris 2012. Francuski latynoamerykanista, profesor na uniwersytecie w Montpellier, specjalizuje się w twórczości Pitola, jest autorem licznych publikacji jej poświęconych i opiekunem prac doktorskich na jej temat, ostatnio ukazały się jego dwa artykuły o odniesieniach do opery i kosmopolityzmie w dziele Meksykanina. 
powtarzający się w jego książkach motyw podróży ${ }^{26}$. Pitola często analizuje się w ujęciu komparatystycznym, zestawia się go z pisarzami z Ameryki Łacińskiej - takimi jak Roberto Bolaño, Jorge Luis Borges czy Ricardo Piglia - jak i niehiszpańskojęzycznymi, np. Carlo Emilio Gadda, Alice Munro i Bruno Schulz²7. Ważnym ośrodkiem badań jego twórczości jest Uniwersytet Veracruzański w Xalapie, na którym pisarz wykładał. Tam po śmierci trafiła jego osobista biblioteka.

Twórczość Pitola zdaje się wspaniałym materiałem dydaktycznym do zajęć akademickich. Na liście lektur znalazłyby się jego dzieła, tłumaczenia, ale i książki pisarzy, na których często się powołuje. Na przykładzie tych tekstów w wielu językach można by wprowadzić mnóstwo pojęć z zakresu teorii literatury - proza ta niemal automatycznie uruchamia refleksję postkolonialną, badania nad przekładem, migracją czy literaturą światową. To mógłby być kurs wprowadzający z zakresu literatury ogólnej i porównawczej, tytuł roboczy: „W osiemdziesiąt literatur dookoła świata. Sergio Pitola podróże literackie". Sama chętnie wzięłabym w nim udział!.

26 Np. do bardzo cenionej przez pisarza Wenecji, zob. O. Vázquez-Medina Myopia and Dazzlement: Visions of Venice in Sergio Pitol, „Bulletin of Spanish Studies” 2018 Vol. 95 No. 4, S. 325-350.

27 Echami opowiadań Brunona Schulza u Pitola zajmowała się Edith Mora Ordóñez La manía de trazar laberintos. Universo polaco y ecos de Bruno Schulz en la narrativa de Sergio Pitol, "Cauce" 2013/2014 No. 36-37, s. 185-206. 


\section{Abstract}

\section{Agnieszka Hudzik}

FREIE UNIVERSITÄT BERLIN

Sergio Pitol: The Relationship Between Central European and Latin American Literature

This article, consisting of four parts and an appendix, is a discussion of the Mexican writer Sergio Pitol (1933-2018), his work and his links to Poland. Hudzik begins by presenting Pitol's life and his most important publications, followed by an account of his visits to Warsaw in the 1960s and 70s. The third part focuses on his contacts with Polish writers Jerzy Andrzejewski and Witold Gombrowicz, whose works Pitol translated into Spanish; Hudzik outlines Pitol's correspondence with Gombrowicz archived at the Beinecke Rare Book \& Manuscript Library. Part four is a reconstruction of Pitol's concept of authorship. The appendix outlines the current state of research on Pitol's work.

\section{Keywords}

Sergio Pitol, contemporary Mexican literature, twentieth-century Polish literature, Spanish translation 